[Regular Paper]

\title{
31P NMR and Mass Spectrometric Studies of the Reaction of Zinc Dialkyldithiophosphates with Cumene Hydroperoxide (Part 1) Kinetics and Mechanisms of the Initial Homolytic Reaction
}

\author{
Kazuhiro Yagishita and Jinichi IgARASHI* \\ Central Technical Research Laboratory, Nippon Oil Co., Ltd., \\ 8 Chidori-cho, Naka-ku, Yokohama 231
}

(Received November 4, 1994)

\begin{abstract}
Initial homolytic reaction of zinc dialkyldithiophosphates, $\left[(\mathrm{RO})_{2} \mathrm{PS}_{2}\right]_{2} \mathrm{Zn}(\mathrm{ZDTPs}, \mathrm{R}=$ iso- $\mathrm{Pr}$ and iso$\mathrm{Bu})$, with cumene hydroperoxide, in benzene solution, has been investigated by applying ${ }^{31} \mathrm{P}$ NMR and mass spectrometry. It is confirmed that the reaction proceeds in two stages, i.e., a rapid oxidation of ZDTPs to 'basic' ZDTPs, [(RO) $\left.)_{2} \mathrm{PS}_{2}\right]_{6} \mathrm{Zn}_{4} \mathrm{O}$, followed by a slower oxidation of basic ZDTP. Rate constants and Arrhenius parameters for these reactions are determined by analyzing the change in the ${ }^{31} \mathrm{P}$ NMR spectra in temperature ranges of $0-34^{\circ} \mathrm{C}$ for ZDTPs and $30-60^{\circ} \mathrm{C}$ for basic ZDTPs. Concentrationtime profiles for the reactions of ZDTP and basic ZDTP with cumene hydroperoxide, respectively, are calculated at $70^{\circ} \mathrm{C}$, where the rate of decomposition of cumene hydroperoxide was previously determined in detail, by using kinetic parameters, which were obtained in this study. It is revealed that ZDTP itself disappears rapidly under this condition and that basic ZDTP formed by the rapid oxidation of ZDTP plays a major role in the initial homolytic decomposition of hydroperoxide. A large tetrahedral cluster molecule of basic ZDTP was detected for the first time in the reaction solution by high resolution mass spectrometric analysis. The molecular ion of basic ZDTP is split into several peaks according to the isotope ratios of the elements, which construct the basic ZDTP. The molecular ion of basic ZDTP is accompanied by several groups of smaller molecular ions, which isotope splitting is almost identical with that of the basic ZDTP. These smaller molecules have molecular weights of basic ZDTP minus $16 n$ and, are assigned basic ZDTP analogous, $\left[(\mathrm{RO})_{2} \mathrm{PS}_{2}\right]_{(6-n)}\left[(\mathrm{RO})_{2} \mathrm{P}(\mathrm{O}) \mathrm{S}\right]_{n} \mathrm{Zn}_{4} \mathrm{O}$ by detailed analysis of the ${ }^{31} \mathrm{P}$ NMR spectra. It is first clarified thus, that the progressive oxidation of basic ZDTP.by hydroperoxide proceeds in such a way as to change the $(\mathrm{RO})_{2} \mathrm{PS}_{2}$ ligand to $(\mathrm{RO})_{2} \mathrm{P}(\mathrm{O}) \mathrm{S}$ ligand. During this reaction, the tetrahedral zinc skeleton of the basic ZDTP is not apparently disrupted.
\end{abstract}

\section{Introduction}

Zinc dialkyldithiophosphates (ZDTPs) have been acknowledged the most important additive in engine oil formulations for over four decades since the additive acts effectively as both antioxidant and antiwear agents. It was previously clarified by several workers ${ }^{1) ~ 12)}$ that hydroperoxides, which are primary oxidation products of lubricant base oils, interact strongly with ZDTPs. The antioxidant property of ZDTPs emerge from the interaction of hydroperoxides and ZDTPs, that decomposes hydroperoxides ${ }^{10)}, 11$. At the same time, it is also known that the interaction of such oxidation products leads to deactivation of the antiwear property of ZDTPs ${ }^{13) \sim 15)}$.

Over 20 years ago, Burn et al.7) had reported that the decomposition of hydroperoxides by ZDTPs

* To whom correspondence should be addressed. occurred in three stages: (a) initial fast stage, (b) slow stage which is referred to as an induction period, (c) final fast stage. These workers further reported that, in the initial fast stage, rates of disappearance of $\left[(\mathrm{RO})_{2} \mathrm{PS}_{2}\right]_{2} \mathrm{Zn}(\mathrm{R}=$ iso- $\mathrm{Pr})$ in chlorobenzene containing excess cumene hydroperoxide are of firstorder with respect to the concentration of ZDTP. Second-order rate constants for this reaction were measured: $1.92 \times 10^{-3}, 2.64 \times 10^{-3}, 7.35 \times 10^{-3}$ and $0.0155 \mathrm{M}^{-1} \mathrm{~s}^{-1}$ at $40^{\circ} \mathrm{C}, 50^{\circ} \mathrm{C}, 60^{\circ} \mathrm{C}$ and $70^{\circ} \mathrm{C}$, respectively. The major product of decomposition of cumene hydroperoxide in this initial reaction is $\alpha, \alpha$-dimethylbenzyl alcohol $(>80 \%)$, which implies homolytic decomposition of cumene hydroperoxide.

Reaction products of ZDTPs in this initial homolytic reaction was also studied by several workers in detail ${ }^{8), 16), 17) . ~ R o s s i ~ a n d ~ I m p a r a t o ~}{ }^{8)}$ have demonstrated that a four fold excess of $\left[(\mathrm{RO})_{2} \mathrm{PS}_{2}\right]_{2} \mathrm{Zn}(\mathrm{R}=i s o-\mathrm{Pr})$ is oxidized by cumene 
hydroperoxide to a basic zinc salt, $\left[(\mathrm{RO})_{2} \mathrm{PS}_{2}\right]_{6} \mathrm{Zn}_{4} \mathrm{O}$ and bis(di-iso-propoxylthiophosphinoyl)disulphide, $\left[(\mathrm{RO})_{2} \mathrm{PS}_{2}\right]_{2}$ (DS), in $\mathrm{CCl}_{4}$ at room temperature (Reaction (1)).

$$
\begin{aligned}
& 4\left[(\mathrm{RO})_{2} \mathrm{PS}_{2}\right]_{2} \mathrm{Zn}+\mathrm{PhCMe}_{2} \mathrm{OOH} \longrightarrow \\
& \quad\left[(\mathrm{RO})_{2} \mathrm{PS}_{2}\right]_{6} \mathrm{Zn}_{4} \mathrm{O}+\left[(\mathrm{RO})_{2} \mathrm{PS}_{2}\right]_{2}+\mathrm{PhCMe}_{2} \mathrm{OH}
\end{aligned}
$$

They have also shown that basic ZDTP is eventually oxidized by excess hydroperoxide to yield zincfree organothiophosphate species and inorganic zinc salts (Reaction (2)).

$$
\begin{gathered}
{\left[(\mathrm{RO})_{2} \mathrm{PS}_{2}\right]_{6} \mathrm{Zn}_{4} \mathrm{O}+15 \mathrm{PhCMe}_{2} \mathrm{OOH} \longrightarrow} \\
1.5\left[(\mathrm{RO})_{2} \mathrm{PS}_{2}\right]_{2}+1.5\left[(\mathrm{RO})_{2} \mathrm{P}(\mathrm{O}) \mathrm{S}\right]_{2}+ \\
\mathrm{ZnO}+3 \mathrm{ZnSO}_{4}+15 \mathrm{PhCMe}_{2} \mathrm{OH}
\end{gathered}
$$

Recently, the ${ }^{31} \mathrm{P}$ NMR spectroscopic technique has been applied to investigate some fundamental reactions of ZDTPs, since it was proved as a very useful and powerful technique ${ }^{16)}$ 22). Paddy et $a l .{ }^{16), 17)}$ investigated in detail the reactions of ZDTPs with hydroperoxide with the ${ }^{31} \mathrm{P}$ NMR spectroscopic technique in combination with the HPLC and Raman spectroscopic techniques. From the reaction solution of basic ZDTP with a twelve fold excess of cumene hydroperoxide in cyclohexane, they identified zinc-free organothiophosphate species, $\left[(\mathrm{RO})_{2} \mathrm{PS}_{2}\right]_{2},\left[(\mathrm{RO})_{2} \mathrm{PS}_{2}\right]_{2} \mathrm{~S}$ and $\left[(\mathrm{RO})_{2} \mathrm{PS}\right]_{2} \mathrm{~S}$, along with a zinc-containing species, zinc dialkylmonothiophosphate $\left[(\mathrm{RO})_{2} \mathrm{P}(\mathrm{O}) \mathrm{S}\right]_{2} \mathrm{Zn}$ (ZMTP). The Raman spectroscopy was used to follow the disappearance of the symmetric $\mathrm{P}-\mathrm{S}$ vibration of the unit $\mathrm{PS}_{2}$ at $540 \mathrm{~cm}^{-1}$ band, characteristic of both ZDTP and basic ZDTP, in the reaction of $0.04 \mathrm{M}\left[(\mathrm{RO})_{2} \mathrm{PS}_{2}\right]_{2} \mathrm{Zn}(\mathrm{R}=n-\mathrm{Bu})$ with $0.12 \mathrm{M}$ cumene hydroperoxide in cyclohexane at $26^{\circ} \mathrm{C}$. Second-order rate constants for a rapid oxidation of ZDTP to basic ZDTP and for a slower oxidation of basic ZDTP by cumene hydroperoxide were measured: $2.4 \times 10^{-3} \mathrm{M}^{-1} \mathrm{~s}^{-1}$ and $2.9 \times 10^{-4}$ $\mathrm{M}^{-1} \mathrm{~s}^{-1}$, respectively. In their ${ }^{31} \mathrm{P} \mathrm{NMR}$ study of the oxidation of basic ZDTPs by cumene hydroperoxide, they observed the development of a 'fine structure' or splitting of the basic ZDTP signal. This was interpreted in terms of the 'progressive break up' of the $\left[(\mathrm{RO})_{2} \mathrm{PS}_{2}\right]_{6} \mathrm{Zn}_{4} \mathrm{O}$ molecule as a result of oxidation. The $\left[(\mathrm{RO})_{2} \mathrm{PS}_{2}\right]_{6} \mathrm{Zn}_{4} \mathrm{O}$ cluster species is known to have a structure with an oxygen surrounded tetrahedrally by four zinc atoms and the $(\mathrm{RO})_{2} \mathrm{PS}_{2}$ ligands attached symmetrically to the six edges of the tetrahedron ${ }^{23)}$.

No doubt, the initial homolytic reaction plays an important role in the practical use of ZDTPs as antioxidants, since ZDTPs usually exist in excess, to hydroperoxides during oxidation of oil in actual service. Despite many studies dedicated to clarify the initial homolytic reaction of ZDTPs with hydroperoxides, there are still some 'discrepancies' in the mechanism of reaction. For example, Sexton $^{24)}$ claims that the slow stage, which is referred to as an induction period, is caused by the production of basic ZDTPs, and that the final rapid ionic decomposition of the hydroperoxide would not begin until the concentration of basic ZDTP is reduced to a critical level. This mechanism does not agree with the Reactions (a) and (b) proposed by Rossi and Imparato ${ }^{8)}$, and the HPLC study by Paddy et al. ${ }^{17)}$, which claims that the decomposition of the hydroperoxide in the initial homolytic reaction is caused by basic ZDTP itself.

In the present paper, the authors report results of investigation of kinetics and mechanisms of the initial homolytic reactions of ZDTPs with cumene hydroperoxide in benzene solution by applying ${ }^{31} \mathrm{P}$ NMR and mass spectrometry. From the study of kinetics by ${ }^{31} \mathrm{P}$ NMR, the authors confirm that the major active species of homolytic hydroperoxide decomposition are basic ZDTPs, as Reaction (b) implies. The result of high resolution mass spectroscopic analysis leads to confirmation of the existence of a large tetrahedral cluster molecule of basic ZDTP, for the first time. New insights of the mechanisms of the oxidation of basic ZDTP by hydroperoxides were attained from results of the high resolution mass spectrometric analysis and the ${ }^{31} \mathrm{P}$ NMR analysis.

\section{Experimental}

\section{1. Materials}

Zinc di-iso-propyldithiophosphate (IPZDTP) and zinc di-iso-butyldithiophosphate (BUZDTP) were prepared from the ammonium salts by metathetical reactions, using aqueous solutions of zinc chloride, referenced on the method of Wystrach ${ }^{25)}$. The purity of ZDTPs was above 95\% by ${ }^{31 P}$ NMR analysis, the main impurity being corresponding basic ZDTPs. Bis(di-iso-butoxylthiophosphinoyl)disulphide (BUDS) was obtained by the oxidation of di-iso-butylphosphorodithioic acid with dimethyl sulfoxide, at room temperature ${ }^{26)}$. Zinc di-iso-butylmonothiophosphate (BUZMTP) was prepared by mixing methanolic solutions of $\mathrm{Zn}\left(\mathrm{NO}_{3}\right)_{2}$ and ammonium di-isobutylmonothiophosphate, prepared as in literature ${ }^{27)}$. All reagents used for preparing the materials were commercial products, and were used without further purification. Cumene hydro- 
Table l ${ }^{31} \mathrm{P}$ NMR Instrument Parameters

\begin{tabular}{lrc}
\hline NMR spectrometer & & JEOL JNM-EX270 \\
31P resonance frequency & {$[\mathrm{MH} z]$} & $\mathrm{C}_{6} \mathrm{D}_{6} / \mathrm{C}_{6} \mathrm{H}_{6}$ \\
Solvent & & $0-60$ \\
Temperature & {$\left[{ }^{\circ} \mathrm{C}\right]$} & 4 \\
Pulse repetition time & {$[\mathrm{sec}]$} & 32 \\
Number of scans & & 10 \\
Sample tube diameter & {$[\mathrm{mm}]$} & \\
\hline
\end{tabular}

Table 2 MS Instrument Parameters

\begin{tabular}{lcc}
\hline MS spectrometer & JEOL JMS-HX110 \\
Ionization mode & & Field desorption \\
Acceleration voltage & {$[\mathrm{kV}]$} & 8 \\
Cathode voltage & {$[\mathrm{kV}]$} & -3 \\
Emitter & & Carbon \\
Mass range & & $35-2000$ \\
\hline
\end{tabular}

peroxide (CHP, 80\% Kishida Chemicals Industry) was purified via its sodium salt, reference O'Brien et al. ${ }^{28)}$. The purity of CHP was confirmed to be above $95 \%$ by ${ }^{13} \mathrm{C}$ NMR analysis. The basic salt of IPZDTP (ca. 90\%) was isolated from the initial reaction solution of IPZDTP and CHP.

\section{2. Instruments and Operating Conditions}

Summarized in Tables $\mathbf{1}$ and $\mathbf{2}$ are the instruments and operating conditions of ${ }^{31} \mathrm{P}$ NMR spectroscopy and mass spectrometry, employed in this study, respectively. Pulse delay of ${ }^{31}$ P NMR was set for 4 seconds, the shortest period within the periods where relative intensity of each peak is not subjected to change. Chemical shifts with respect to $85 \% \mathrm{H}_{3} \mathrm{PO}_{4}$ are reported.

2. 3. Observation of Time Evolution of Phosphorus-containing Species in the Reaction of ZDTPs with CHP by in situ ${ }^{31}$ P NMR Spectroscopy

Benzene solution of ZDTP was heated in an NMR sample tube at reaction temperature. Immediately after adding CHP into the solution, the sample tube was set into the NMR probe, which was maintained at reaction temperature. The time evolution of phosphorus-containing species was monitored by the in situ ${ }^{31} \mathrm{P}$ NMR.

\section{Results}

3. 1. Observation of Time Evolution of Phosphorus-containing Species in the Reaction of ZDTPs with CHP by ${ }^{31}$ P NMR

Oxidation of $0.025 \mathrm{M}$ ZDTPs by $0.25 \mathrm{M}$ CHP in benzene solution, at temperature ranges of $0-60^{\circ} \mathrm{C}$, was monitored by ${ }^{31} \mathrm{P}$ NMR spectroscopy. Shown in Fig. 1 is the time evolution of ${ }^{31 P}$ NMR spectrum during oxidation of $0.025 \mathrm{M}$ BUZDTP by $0.25 \mathrm{M}$ CHP in benzene at $40^{\circ} \mathrm{C}$. The ZDTP peak $(99.0 \mathrm{ppm})$ rapidly decays and is replaced by the peaks of basic ZDTP (ca. 103 ppm) and DS (86.0

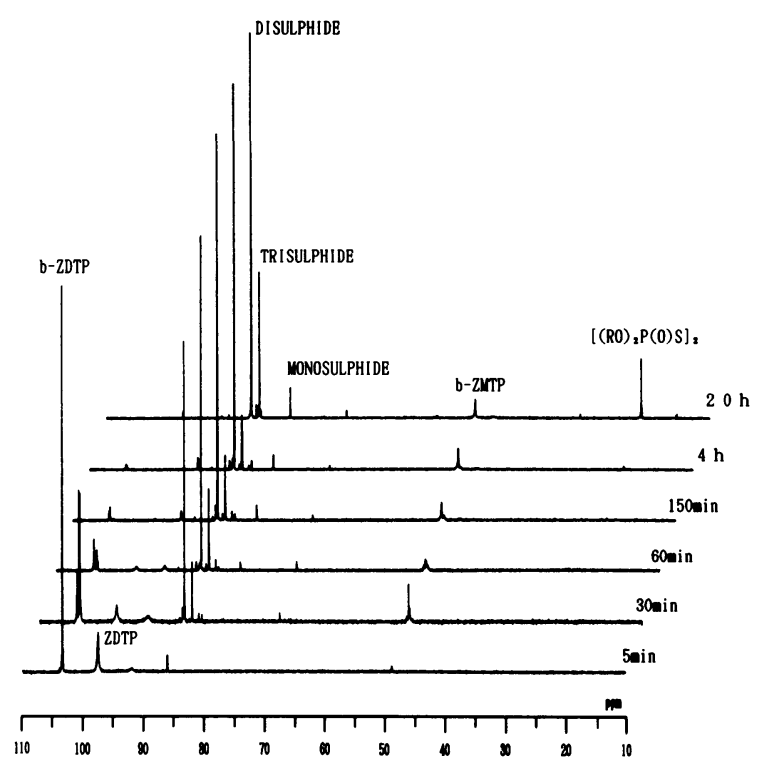

Fig. l Time Dependence of the ${ }^{31} \mathrm{P}$ NMR Spectrum during Oxidation Process of $0.025 \mathrm{M}$ BUZDTP with $0.25 \mathrm{M}$ Cumene Hydroperoxide in Benzene at $40^{\circ} \mathrm{C}$

ppm) in $5 \mathrm{~min}$, as was previously observed by Paddy et al. ${ }^{16)}$. Basic ZDTP is subsequently oxidized, as the intensity of the peak at $c a .103 \mathrm{ppm}$ declines showing a slight splitting, and peaks at higher fields, $84.4 \mathrm{ppm}, 79.0 \mathrm{ppm}$ and $49 \mathrm{ppm}$ develop. The peaks at $84.4 \mathrm{ppm}$ and $79.0 \mathrm{ppm}$ have been assigned by Paddy et al.16),17) to trisulphide, $\left[(\mathrm{RO})_{2} \mathrm{PS}_{2}\right]_{2} \mathrm{~S}$, and monosulphide, $\left[(\mathrm{RO})_{2} \mathrm{PS}\right] \mathrm{S}_{2}$, respectively. The authors have confirmed these assignments, also by mass spectrometric analysis (see below). Paddy et al. have provisionally assigned the peak at $c a .49 \mathrm{ppm}$ as the zinc salt of dialkylmonothiophosphate, $\left[(\mathrm{RO})_{2} \mathrm{P}(\mathrm{O}) \mathrm{S}\right]_{2} \mathrm{Zn}(\mathrm{ZMTP})$. The authors concur with this assignment, in part. More precisely, the authors assign this to $(\mathrm{RO})_{2} \mathrm{P}(\mathrm{O}) \mathrm{S}$ ligand attached to the basic salt, $\left[(\mathrm{RO})_{2} \mathrm{PS}_{2}\right]_{(6-n)}\left[(\mathrm{RO})_{2} \mathrm{P}(\mathrm{O}) \mathrm{S}\right]_{n} \mathrm{Zn}_{4} \mathrm{O}$ (see below).

The peaks of basic ZDTP at ca. $103 \mathrm{ppm}$ completely disappear after $4 \mathrm{~h}$ of reaction. Subsequently, the peak of basic ZMTP at $49 \mathrm{ppm}$ starts to decline and a new peak at higher field, $22.1 \mathrm{ppm}$, develops after $20 \mathrm{~h}$ (Fig. 1). This peak was assigned to bis(dialkoxylphosphinoyl)disulfide, $\left[(\mathrm{RO})_{2} \mathrm{P}(\mathrm{O}) \mathrm{S}\right]_{2}$, from the chemical shift ${ }^{29)}$. Since the intensity of this peak increases as the peak at $49 \mathrm{ppm}$ declines, the authors assume that this 'disulphide' is produced from the oxidation of the basic ZMTP by CHP. The decline of the peak of basic ZMTP at 49 ppm and the development of $22.1 \mathrm{ppm}$ peak were not observed by Paddy et al. within the time span of their experiments. It 


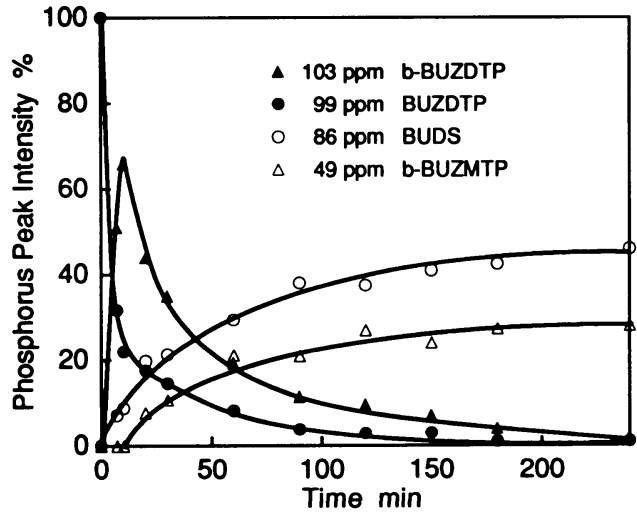

Fig. 2 Time Dependence of Intensities of the Observed ${ }^{31} \mathrm{P}$ NMR Signals during Oxidation Process of $0.025 \mathrm{M}$ BUZDTP with $0.25 \mathrm{M}$ Cumene Hydroperoxide in Benzene at $40^{\circ} \mathrm{C}$

should be noted that, even within the much longer time span of the authors' experiments, the signal intensities of zinc-free organothiophosphate species, DS (86.0 ppm), trisulphide (84.4 ppm), monosulphide (79.0 ppm) and phosphinoyl disulphide (22.0 ppm) increase continuously, while the peaks of zinc-containing species, ZDTP (99.0 ppm), basic ZDTP (103 ppm) and basic ZMTP (49 ppm) decline. This fact confirms the previous observation $^{7)}$ : the rates of oxidation of the zinc-free organothiophosphate species by CHP are much slower than those of zinc-containing species. It is, therefore, concluded that the active species of CHP decomposition in the initial homolytic reaction are zinc-containing species.

\section{2. Kinetic Analysis of Reactions of ZDTP and Basic ZDTP with CHP}

Reactions of 0.025-0.05 M ZDTPs with 0.1$0.25 \mathrm{M} \mathrm{CHP}$, at temperature ranges of $0-60^{\circ} \mathrm{C}$, were monitored by in situ ${ }^{31} \mathrm{P}$ NMR spectroscopy. Changes in the intensities of signals shown in Fig. 1 are plotted and shown in Fig. 2. The second-order rate constants for the reaction of ZDTPs and basic ZDTPs with CHP are calculated from the pseudo first-order rate constants, which are derived by assuming the constant concentration of CHP over the initial period of reaction. They are obtained via Eq. (1):

$$
-\frac{\mathrm{d}[\mathrm{A}]}{\mathrm{d} t}=k_{1}^{\prime}[\mathrm{A}]=k_{1}[\mathrm{CHP}][\mathrm{A}]
$$

where A represents ZDTP or basic ZDTP, and $k_{1}$ ' and $k_{1}$ the pseudo first-order and the second-order rate constant, respectively. It should be noted that the total intensities of the slightly splitting peaks at $c a .103 \mathrm{ppm}$ were used to calculate the rate constants for the reaction of basic ZDTP with
Table 3 Rate Constants and Arrhenius Parameters for the Reaction of ZDTPs with CHP in Benzene Solution ${ }^{\text {a) }}$

\begin{tabular}{ccc}
\hline \multirow{2}{*}{$\begin{array}{c}\text { Temperature } \\
{\left[{ }^{\circ} \mathrm{C}\right]}\end{array}$} & \multicolumn{2}{c}{$k_{1}\left[\mathrm{M}^{-1} \mathrm{~s}^{-1}\right]$} \\
\cline { 2 - 3 } & IPZDTP & BUZDTP \\
\hline 0 & $1.45 \times 10^{-3}$ & $\left.1.02 \times 10^{-3} \mathrm{~b}\right)$ \\
10 & $1.99 \times 10^{-3}$ & $3.83 \times 10^{-3}$ \\
20 & $1.40 \times 10^{-2}$ & $1.92 \times 10^{-2}$ \\
54 & $\left(4.42 \times 10^{-2}\right)^{\mathrm{c}}$ & $2.92 \times 10^{-2}$ \\
50 & $(0.20)^{\mathrm{c})}$ & $(0.16)^{\mathrm{c}}$ \\
70 & 9.96 & $(0.78)^{\mathrm{c})}$ \\
$\log \left[\mathrm{A} / \mathrm{M}^{-1} \mathrm{~s}^{-1}\right]$ & 16.83 & 10.78 \\
$\mathrm{Ea}\left[\mathrm{kcal} / \mathrm{mol}^{\mathrm{m}}\right]$ & 17.20 \\
\hline
\end{tabular}

a) $[$ ZDTPs $] /[\mathrm{CHP}]=0.05 \mathrm{M} / 0.10 \mathrm{M}$. b) In hexane solution.

c) Extrapolated.

Table 4 Rate Constants and Arrhenius Parameters for the Reaction of Basic ZDTPs with CHP in Benzene Solution ${ }^{\text {a) }}$

\begin{tabular}{|c|c|c|}
\hline \multirow{2}{*}{$\begin{array}{c}\text { Temperature } \\
{\left[{ }^{\circ} \mathrm{C}\right]}\end{array}$} & \multicolumn{2}{|c|}{$k_{1}^{\mathrm{b}} / \mathrm{Zn}^{\mathrm{b})}\left[\mathrm{M}^{-1} \mathrm{~s}^{-1}\right]$} \\
\hline & IPZDTP & BUZDTP \\
\hline 30 & $3.20 \times 10^{-4}$ & - \\
\hline 40 & $8.04 \times 10^{-4}$ & $1.57 \times 10^{-3}$ \\
\hline 50 & $2.81 \times 10^{-3}$ & $\left.\left(4.36 \times 10^{-3}\right)^{d}\right)$ \\
\hline 60 & $6.16 \times 10^{-3}$ & - \\
\hline 70 & $\left.\left(1.84 \times 10^{-2}\right)^{c}\right)$ & $\left.\left(2.73 \times 10^{-2}\right)^{\mathrm{d}}\right)$ \\
\hline $\log \left[A / M^{-1} s^{-1}\right]$ & 11.13 & $\left.(11.30)^{\mathrm{e}}\right)^{\prime}$ \\
\hline$E a[\mathrm{kcal} / \mathrm{mol}]$ & 20.32 & $(20.32)^{\mathrm{e}}$ \\
\hline
\end{tabular}

a) $[$ ZDTPs $] /[\mathrm{CHP}]=0.025 \mathrm{M} / 0.25 \mathrm{M}$. b) Per zinc atom. c) Extrapolated. d) Obtained from the estimated Arrhenius parameters. e) Based on the assumption that the same $E a$ value as the IPZDTP could be applied to the BUZDTP.

CHP. Hence, all of the $(\mathrm{RO})_{2} \mathrm{PS}_{2}$ ligand that were attached to the tetrahedral $\mathrm{OZn}_{4}$ framework was accounted for as the basic ZDTP, regardless of the coexistence of $(\mathrm{RO})_{2} \mathrm{P}(\mathrm{O}) \mathrm{S}$ ligand in the same 'basic' $\mathrm{OZn}_{4}$ framework (the splitting of peaks of $(\mathrm{RO})_{2} \mathrm{PS}_{2}$ ligand indicates that the $(\mathrm{RO})_{2} \mathrm{P}(\mathrm{O}) \mathrm{S}$ ligand coexists in the same $\mathrm{OZn}_{4}$ framework, see below).

Values of the second-order rate constants for the reaction of ZDTPs and basic ZDTPs with CHP are given in Tables 3 and 4 , respectively. It is noted that, for easier comparison, the rate constants for basic ZDTPs are given as $k_{1}$ ber zinc atom. It can be seen from Tables 3 and 4 that the reaction of ZDTPs with CHP proceeds in one or two magnitudes faster than that of basic ZDTPs with CHP. It is also seen that values of both $k_{1}$ and $k_{1}$ b of BUZDTP are two to three times greater than those of IPZDTP. Burn et al. have measured the rate of disappearance of IPZDTP, during the initial reaction with CHP in chlorobenzene, by potentiometric titration with silver nitrate. They reported the rate constants: $k_{1}=1.92 \times 10^{-3}, 2.64 \times$ $10^{-3}$ (average), $7.35 \times 10^{-3}$ and $0.0155 \mathrm{M}^{-1} \mathrm{~s}^{-1}$ at $40^{\circ} \mathrm{C}$, $50^{\circ} \mathrm{C}, 60^{\circ} \mathrm{C}$ and $70^{\circ} \mathrm{C}$, respectively. These values are in good agreement with the rate constants for the reaction of basic IPZDTP with CHP obtained 
in this study: $k_{1} \mathrm{~b}=0.804 \times 10^{-3}, 2.81 \times 10^{-3}, 6.16 \times 10^{-3}$ and $0.0184 \mathrm{M}^{-1} \mathrm{~s}^{-1}$ (extrapolated), respectively (Table 4). It is, therefore, very likely that Burn measured the rate of disappearance of basic IPZDTP by potentiometric titration with silver nitrate. Since Burn claims that the rate of IPZDTP disappearance 'parallels' that of CHP decomposition, it can be concluded that the major species of hydroperoxide decomposition is not ZDTP itself, but basic ZDTP produced by rapid oxidation by hydroperoxide.

Ohkatsu et al. have measured the rates of CHP decomposition by BUZDTP in chlorobenzene at $70^{\circ} \mathrm{C}^{30}$ ). The initial rates of CHP decomposition were first-order with respect to both CHP and BUZDTP concentrations, i.e., the rates were in accordance with Eq. (2):

$$
-\frac{\mathrm{d}[\mathrm{CHP}]}{\mathrm{d} t}=k_{\mathrm{d}}[\mathrm{CHP}][\mathrm{ZDTP}]
$$

The rate constant $k_{\mathrm{d}}$ was reported: $0.0207 \mathrm{M}^{-1} \mathrm{~s}^{-1}$, which is comparable to the value of rate constant of disappearance of the basic ZDTPs: $0.0273 \mathrm{M}^{-1} \mathrm{~s}^{-1}$ at $70^{\circ} \mathrm{C}$, which the authors obtained (Table 4). In order to confirm that basic ZDTP is also the major CHP decomposition species under this condition, the reaction profiles for $Z$ DTP and basic ZDTP has been calculated using rate constants obtained in this study. Assuming that the concentration of CHP is constant at very early stage of CHP decomposition (conversion $<10 \%$ ), reaction of ZDTP and basic ZDTP can be expressed by twostep consecutive first-order reaction (Eqs. (3) and (4)).

$$
\begin{aligned}
& \frac{\mathrm{d}[\mathrm{ZDTP}]}{\mathrm{d} t}=-k_{1}{ }^{\prime}[\mathrm{ZDTP}] \\
& \frac{\mathrm{d}[\mathrm{b}-\mathrm{ZDTP}]}{\mathrm{d} t}=k_{1}{ }^{\prime}[\mathrm{ZDTP}]-k_{1}{ }^{\mathrm{b}}[\mathrm{b}-\mathrm{ZDTP}]
\end{aligned}
$$

where $k_{1}$ ' and $k_{1}{ }^{\text {b }}$ are the pseudo first-order rate constants for ZDTP and basic ZDTP reaction. Equations (3) and (4) are readily solved and concentration-time profiles of ZDTP and basic ZDTP are given by Eqs. (5) and (6), respectively.

$$
\begin{aligned}
& {[\mathrm{ZDTP}]=[\mathrm{ZDTP}]_{0} \exp \left(-k_{1}{ }^{\prime} t\right)} \\
& {[\mathrm{b}-\mathrm{ZDTP}]=\frac{k_{1}{ }^{\prime}[\mathrm{ZDTP}]_{0}}{k_{1}{ }^{\mathrm{b}}-k_{1}{ }^{\prime}}\left\{\exp \left(-k_{1}{ }^{\prime} t\right)-\exp \left(-k_{1}{ }^{\mathrm{b}} t\right)\right\}}
\end{aligned}
$$

The concentration-time profiles of ZDTP and

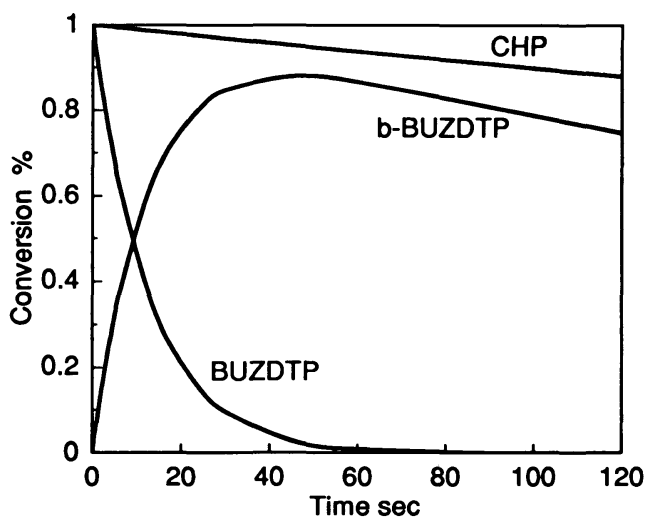

Fig. 3 Concentration-time Profiles for Early Stage of Reaction of $0.05 \mathrm{M}$ BUZDTP with $0.10 \mathrm{M}$ Cumene Hydroperoxide at $70^{\circ} \mathrm{C}$

basic ZDTP are calculated at $[\mathrm{CHP}]_{0}=0.1 \mathrm{M}$ and $[\text { ZDTP }]_{0}=0.05 \mathrm{M}$ with $k_{1}{ }^{\prime}=0.078 \mathrm{~s}^{-1}$ and $k_{1}{ }^{\mathrm{b}}=0.00273$ $\mathrm{s}^{-1}$ and $k_{\mathrm{d}}=0.0207 \mathrm{M}^{-1} \mathrm{~s}^{-1}$. Results of the calculation are shown in Fig. 3. As expected from the rate constants, ZDTP itself quickly disappeared within one minute. It is clear that basic ZDTP, derived from ZDTP, play a major role in this very early stage of CHP decomposition, where $k_{\mathrm{d}}$ value was determined ${ }^{30}$.

These experimental results strongly support the mechanisms proposed by Rossi and Imparato for the initial homolytic reaction, that is: excess moles of CHP are decomposed by basic ZDTP, which is produced by rapid oxidation of ZDTP.

\section{3. ${ }^{31 P}$ NMR and Mass Spectrometric Analyses of Reaction of Basic ZDTP with CHP}

Reaction of basic ZDTP with CHP, which is now confirmed to be the major reaction in the initial homolytic decomposition of CHP, has been studied by ${ }^{31} \mathrm{P}$ NMR and high resolution mass spectrometry in detail. Shown in Fig. 4 is the ${ }^{31} \mathrm{P}$ NMR spectrum shown in Fig. 1 focused on the peaks of basic BUZDTP at $c a$. $103 \mathrm{ppm}$. It can be seen from Fig. 1 that initial single peak of basic BUZDTP at 103.4 ppm breaks into several peaks, as the reaction proceeds. This slight splitting or 'fine structure' of the peaks of basic ZDTP was previously observed by Paddy $e$ al.${ }^{16)}$ and was attributed to 'break up' by progressive oxidation of $\left[(\mathrm{RO})_{2} \mathrm{PS}_{2}\right]_{6} \mathrm{Zn}_{4} \mathrm{O}$ cluster species. They have claimed that initial oxidation step involves oxidant (hydroperoxide) attack at a zinc atom with concomitant breakage of a $\mathrm{Zn}-\mathrm{S}$ bond at the atom attacked, and further oxidation events involve further breakage of $\mathrm{Zn}-\mathrm{S}$ bond. They have suggested that, as long as the number of such breakage of bond is not too great, the tetrahedral $\mathrm{OZn}_{4}$ central framework is not disrupted.

The authors' detailed ${ }^{31} \mathrm{P}$ NMR analysis revealed that the peak at around $49 \mathrm{ppm}$ which was 


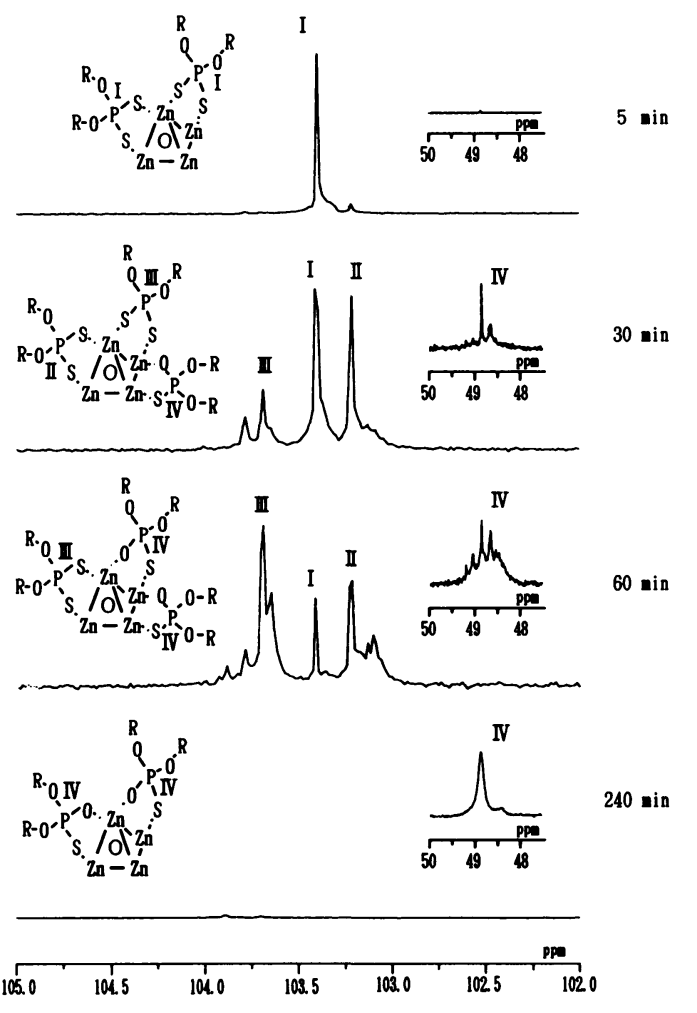

Fig. 4 Change in the ${ }^{31} \mathrm{P}$ NMR Spectra (102-105 ppm and around $49 \mathrm{ppm}$ ) during Oxidation Process of $0.025 \mathrm{M}$ BUZDTP with $0.25 \mathrm{M}$ Cumene Hydroperoxide in Benzene at $40^{\circ} \mathrm{C}$

assigned to $\left[(\mathrm{RO})_{2} \mathrm{P}(\mathrm{O}) \mathrm{S}\right]_{2} \mathrm{Zn}$ by Paddy et al. appeared as soon as splitting of the peak of basic ZDTP started. Moreover, the peak at $49 \mathrm{ppm}$ also showed a slight splitting similarly as those of basic ZDTP, and splitting of the peak synchronized to that of basic ZDTP (see Fig. 4). The authors, in contrast with Paddy et al., attributed these splitting of the peaks to progressive oxidation of $(\mathrm{RO})_{2} \mathrm{PS}_{2}$ ligand to $(\mathrm{RO})_{2} \mathrm{P}(\mathrm{O}) \mathrm{S}$ ligand, while apparently maintaining the tetrahedral $\mathrm{OZn}_{4}$ central framework structure. Thus, the authors have assumed that splitting of the peaks of $(\mathrm{RO})_{2} \mathrm{PS}_{2}$ ligand is brought by influence of $(\mathrm{RO})_{2} \mathrm{P}(\mathrm{O}) \mathrm{S}$ ligand attached to the same basic ZDTP cluster. The basic ZDTP molecule having no $(\mathrm{RO})_{2} \mathrm{P}(\mathrm{O}) \mathrm{S}$ ligand, i.e., $\left[(\mathrm{RO})_{2} \mathrm{PS}_{2}\right]_{6} \mathrm{Zn}_{4} \mathrm{O}$ itself, shows single peak at $103.4 \mathrm{ppm}$ (peak I). Partially oxidized basic ZDTP molecules having $(\mathrm{RO})_{2} \mathrm{P}(\mathrm{O}) \mathrm{S}$ ligands, $\left[(\mathrm{RO})_{2} \mathrm{PS}_{2}\right]_{(6-n)}\left[(\mathrm{RO})_{2} \mathrm{P}(\mathrm{O}) \mathrm{S}\right]_{n} \mathrm{Zn}_{4} \mathrm{O}$, evolve several peaks mainly at $103.2 \mathrm{ppm}$ (peak II) and 103.7 ppm (peak III). Since signal intensity of peak II is higher at initial stage of ligand oxidation, the authors assign peak II to the $(\mathrm{RO})_{2} \mathrm{PS}_{2}$ ligand which is not attached to the zinc atom acquiring $(\mathrm{RO})_{2} \mathrm{P}(\mathrm{O}) \mathrm{S}$ ligand. Peak III should be assigned to the $(\mathrm{RO})_{2} \mathrm{PS}_{2}$ ligand attached to the zinc atom

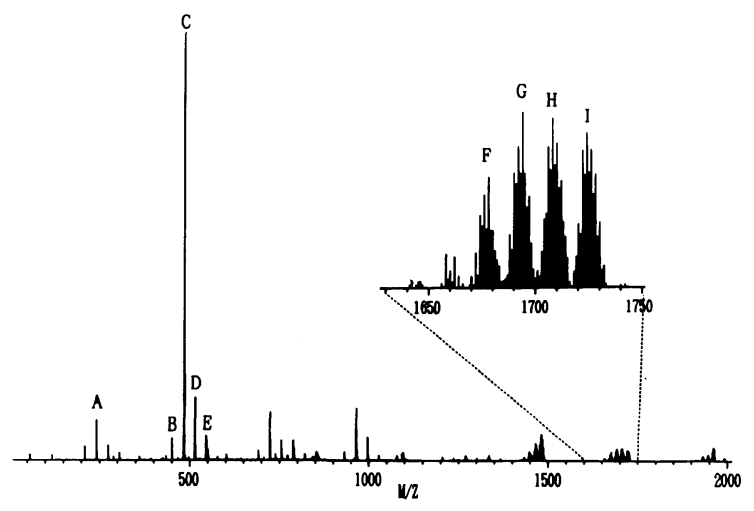

Fig. 5 Mass Spectrum for the Reaction Products of 0.025 M BUZDTP with 0.25 M Cumene Hydroperoxide after $30 \mathrm{~min}$ at $40^{\circ} \mathrm{C}$

Table 5 Assignment of the Peaks Appeared in the Mass Spectrum for the Reaction Solution of BUZDTP and CHP at $40^{\circ} \mathrm{C}$ after $30 \mathrm{~min}$

\begin{tabular}{|c|c|c|}
\hline Peak & Mass number & Assignment \\
\hline A & 241 & $\left(\mathrm{C}_{4} \mathrm{H}_{9} \mathrm{O}\right)_{2} \mathrm{PS}_{2}$ \\
\hline $\mathrm{B}$ & 450 & {$\left[\left(\mathrm{C}_{4} \mathrm{H}_{9} \mathrm{O}\right)_{2} \mathrm{PS}\right]_{2} \mathrm{~S}$} \\
\hline C & 482 & {$\left[\left(\mathrm{C}_{4} \mathrm{H}_{9} \mathrm{O}\right)_{2} \mathrm{PS}_{2}\right]_{2}$} \\
\hline $\mathrm{D}$ & 514 & {$\left[\left(\mathrm{C}_{4} \mathrm{H}_{9} \mathrm{O}\right)_{2} \mathrm{PS}_{2}\right]_{2} \mathrm{~S}$} \\
\hline $\mathrm{E}$ & 546 & {$\left[\left(\mathrm{C}_{4} \mathrm{H}_{9} \mathrm{O}\right)_{2} \mathrm{PS}_{2}\right]_{2} \mathrm{Zn}$} \\
\hline $\mathbf{F}$ & $1670-1784$ & {$\left[\left(\mathrm{C}_{4} \mathrm{H}_{9} \mathrm{O}\right)_{2} \mathrm{PS}_{2}\right]_{3}\left[\left(\mathrm{C}_{4} \mathrm{H}_{9} \mathrm{O}\right)_{2} \mathrm{P}(\mathrm{O}) \mathrm{S}_{3} \mathrm{Zn}_{4} \mathrm{O}\right.$} \\
\hline G & $1686-1700$ & {$\left[\left(\mathrm{C}_{4} \mathrm{H}_{9} \mathrm{O}\right)_{2} \mathrm{PS}_{2}\right]_{4}\left[\left(\mathrm{C}_{4} \mathrm{H}_{9} \mathrm{O}\right)_{2} \mathrm{P}(\mathrm{O}) \mathrm{S}_{2} \mathrm{Zn}_{4} \mathrm{O}\right.$} \\
\hline $\mathrm{H}$ & $1702-1716$ & {$\left[\left(\mathrm{C}_{4} \mathrm{H}_{9} \mathrm{O}\right)_{2} \mathrm{PS}_{2}\right]_{5}\left[\left(\mathrm{C}_{4} \mathrm{H}_{9} \mathrm{O}\right)_{2} \mathrm{P}(\mathrm{O}) \mathrm{S}\right] \mathrm{Zn}_{4} \mathrm{O}$} \\
\hline I & $1718-1732$ & {$\left[\left(\mathrm{C}_{4} \mathrm{H}_{9} \mathrm{O}\right)_{2} \mathrm{PS}_{2}\right]_{6} \mathrm{Zn}_{4} \mathrm{O}$} \\
\hline
\end{tabular}

acquiring $(\mathrm{RO})_{2} \mathrm{P}(\mathrm{O}) \mathrm{S}$ ligand.

For the purpose to confirm this assumption, the authors have utilized high resolution mass spectrometry and attempted to arrest molecular species which are produced in the reaction process. Shown in Fig. 5 is the high resolution FD-MS spectrum for reaction solution of $0.025 \mathrm{M}$ BUZDTP and $0.25 \mathrm{M} \mathrm{CHP}$, after a reaction period of $30 \mathrm{~min}$ at $40^{\circ} \mathrm{C}$ (to see the extent of the reaction, refer to ${ }^{31} \mathrm{P}$ NMR spectra in Figs. 1 and 4). Results of the assignment of the peaks are summarized in Table 5. The strongest peak at $M / Z=482$ (peak C), and the neighboring $M / Z=450$ (peak B) and $M / Z=514$ (peak D) are assigned to DS, monosulphide and trisulphide, respectively. The unreacted BUZDTP is detected at $M / Z=546$ (peak E). Several groups of peaks detected around $M / Z=$ 1700 (peak Groups F, G, H, I) are particularly important and should be noted. The peak pattern for peak Group I of the highest $M / Z$, around 1724, is shown in Fig. 6(a). It is remarkable that the experimental peak pattern coincides with the theoretical pattern for basic BUZDTP cluster molecule, which is calculated by taking into account the isotope ratio of elements that construct $\left[(\mathrm{RO})_{2} \mathrm{PS}_{2}\right]_{6} \mathrm{Zn}_{4} \mathrm{O}($ Fig. 6(b)). Hence, peak Group 

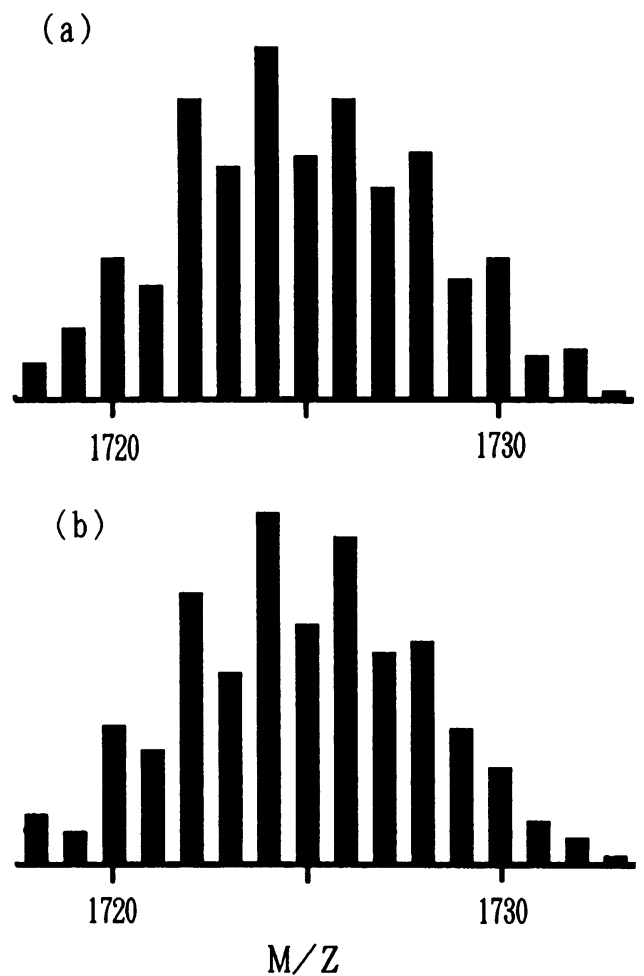

Fig. 6 Comparison between the Measured Pattern (a) and the Theoretical Pattern (b) Corresponding to the Molecular Ions of the Basic BUZDTP

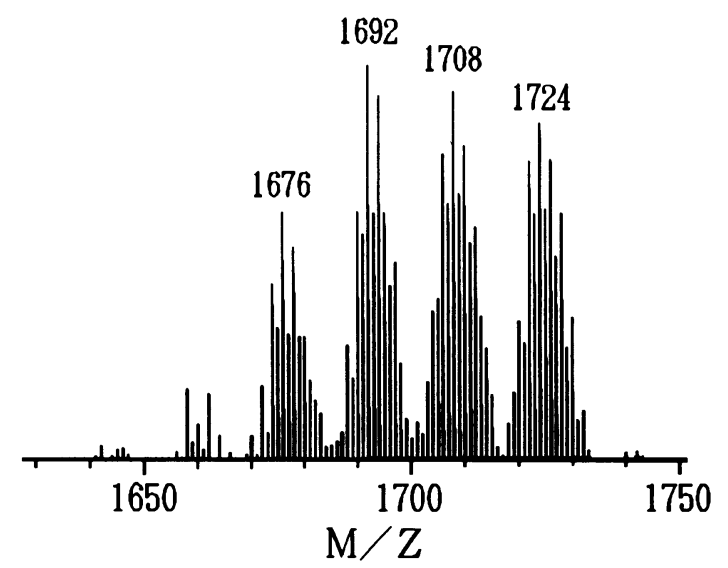

Fig. 7 Mass Spectrum around $M / Z=1700$ for the Reaction Products of $0.025 \mathrm{M}$ BUZDTP with $0.25 \mathrm{M}$ Cumene Hydroperoxide after $30 \mathrm{~min}$ at $40^{\circ} \mathrm{C}$

I is clearly assigned to basic BUZDTP. The existence of a large tetrahedral cluster molecule of basic ZDTP is now confirmed, for the first time, by the high resolution mass spectrometry. It is clearly seen from the enlarged mass spectrum around $M / Z 1700$ (Fig. 7), that peak Groups F, G, and H are almost identical in pattern with that of peak Group I. These peak groups should be assigned as basic ZDTP analogous, produced by progressive oxidation of $(\mathrm{RO})_{2} \mathrm{PS}_{2}$ ligand to $(\mathrm{RO})_{2} \mathrm{P}(\mathrm{O}) \mathrm{S}$, since they align at an interval of $M / Z=16$. This assignment is in consistency with that of the ${ }^{31} \mathrm{P}$ NMR study (see above).

As could be seen from the ${ }^{31} \mathrm{P}$ NMR spectrum in Fig. 4, peaks at around $103 \mathrm{ppm}$ corresponding to $(\mathrm{RO})_{2} \mathrm{PS}_{2}$ ligand in basic ZDTP, disappear after 240 min. Concurrently, split peaks at around $49 \mathrm{ppm}$ corresponding to $(\mathrm{RO})_{2} \mathrm{P}(\mathrm{O}) \mathrm{S}$ ligand (peak $\mathrm{IV}$ ) is unified to single peak at $49.0 \mathrm{ppm}$. It is important to note that this peak is shifted $3 \mathrm{ppm}$ downfield from $46.0 \mathrm{ppm}$, where the resonance of BUZMTP, $\left[(\mathrm{RO})_{2} \mathrm{P}(\mathrm{O}) \mathrm{S}\right]_{2} \mathrm{Zn}$, is observed. Considering the fact that a similar downfield shift occurs in structural change of ZDTP to basic ZDTP, the single peak at $49.0 \mathrm{ppm}$ should be assigned to 'basic ZMTP' cluster species, $\left[(\mathrm{RO})_{2} \mathrm{P}(\mathrm{O}) \mathrm{S}\right]_{6} \mathrm{Zn}_{4} \mathrm{O}$. It was thus concluded that the tetrahedral zinc skeleton of basic ZDTP was apparently held during progressive oxidation of basic ZDTP by hydroperoxide, which leads to total replacement of $(\mathrm{RO})_{2} \mathrm{PS}_{2}$ ligand to $(\mathrm{RO})_{2} \mathrm{P}(\mathrm{O}) \mathrm{S}$ ligand.

\section{Discussion}

On the basis of experimental results obtained in this study, the authors can now propose overall reaction mechanisms, for the initial homolytic reaction of ZDTP with hydroperoxide. Since it is well established that ZDTPs are readily oxidized to basic ZDTPs and DS (Reaction (1)), the following reaction mechanisms concentrate on oxidation of basic ZDTPs by hydroperoxide.

$$
\begin{aligned}
& \text { Oxidation of ZDTP to Basic ZDTP } \\
& \quad 4\left[(\mathrm{RO})_{2} \mathrm{PS}_{2}\right]_{2} \mathrm{Zn}+\mathrm{PhCMe}_{2} \mathrm{OOH} \longrightarrow \\
& \quad\left[(\mathrm{RO})_{2} \mathrm{PS}_{2}\right]_{6} \mathrm{Zn}_{4} \mathrm{O}+\left[(\mathrm{RO})_{2} \mathrm{PS}_{2}\right]_{2}+\mathrm{PhCMe}_{2} \mathrm{OH}
\end{aligned}
$$

Initial Oxidation of the Basic ZDTP-A

$$
\begin{aligned}
& {\left[(\mathrm{RO})_{2} \mathrm{PS}_{2}\right]_{6} \mathrm{Zn}_{4} \mathrm{O}+4 \mathrm{PhCMe}_{2} \mathrm{OOH} \longrightarrow} \\
& 2\left[(\mathrm{RO})_{2} \mathrm{PS}_{2}\right]_{2} \mathrm{Zn}+\left[(\mathrm{RO})_{2} \mathrm{PS}_{2}\right]\left[(\mathrm{RO})_{2} \mathrm{P}(\mathrm{O}) \mathrm{S}\right] \mathrm{Zn}+ \\
& \mathrm{ZnSO}_{4}+4 \mathrm{PhCMe}_{2} \mathrm{OH}
\end{aligned}
$$

Initial Oxidation of the Basic ZDTP-B

$$
\begin{aligned}
& {\left[(\mathrm{RO})_{2} \mathrm{PS}_{2}\right]_{6} \mathrm{Zn}_{4} \mathrm{O}+5 \mathrm{PhCMe}_{2} \mathrm{OOH} \longrightarrow} \\
& {\left[(\mathrm{RO})_{2} \mathrm{PS}_{2}\right]_{2} \mathrm{Zn}+\left[(\mathrm{RO})_{2} \mathrm{PS}_{2}\right]\left[(\mathrm{RO})_{2} \mathrm{P}(\mathrm{O}) \mathrm{S}\right] \mathrm{Zn}+} \\
& {\left[(\mathrm{RO})_{2} \mathrm{PS}_{2}\right]_{2}+\mathrm{ZnO}+\mathrm{ZnSO}_{4}+5 \mathrm{PhCMe}_{2} \mathrm{OH}}
\end{aligned}
$$


It is known that CHP attacks basic ZDTP at a zinc atom, and CHP decomposes homolytically to generate cumyloxyl and hydroxyl radicals ${ }^{16)}$. These radicals may oxidize $(\mathrm{RO})_{2} \mathrm{PS}_{2}$ ligand and zinc atom. The oxidation of $(\mathrm{RO})_{2} \mathrm{PS}_{2}$ ligand leads to the formation of $(\mathrm{RO})_{2} \mathrm{P}(\mathrm{O}) \mathrm{S}$ ligand and sulfur oxides $\left(\mathrm{SO}_{2}, \mathrm{SO}_{3}\right)$. Sulfur oxides are susceptible to be neutralized by basic ZDTP molecule yielding zinc sulfate, $\mathrm{ZnSO}_{4}$ (Reaction $(3 \mathrm{~A}-\mathrm{i}))$. Formation of zinc oxide, $\mathrm{ZnO}$, is also confirmed in this reaction system, indicating that oxidation of zinc atom occurs concurrently with the oxidation of ligand (Reaction (3B-i)).

It is highly likely that the reaction of CHP and basic ZDTP leads to destruction of the tetrahedral structure of basic ZDTP, as described in Reactions $(3 \mathrm{~A}-\mathrm{i})$ and $(3 \mathrm{~B}-\mathrm{i})^{* 1)}$. $(\mathrm{RO})_{2} \mathrm{P}(\mathrm{O}) \mathrm{S}$ ligand in the resulting zinc salt, $\left[(\mathrm{RO})_{2} \mathrm{P}(\mathrm{O}) \mathrm{S}\right]\left[(\mathrm{RO})_{2} \mathrm{PS}_{2}\right] \mathrm{Zn}$, may easily be incorporated into the tetrahedral structure of basic ZDTP either via a rapid ligand exchange reaction (Reaction (4)) $)^{31)}$ or via rapid oxidation by hydroperoxide (Reaction (5))*2). Through these reactions, the structure of the tetrahedral zinc skeleton of the basic ZDTP is apparently undisrupted.

Ligand Exchange Reaction

$$
\begin{aligned}
& {\left[(\mathrm{RO})_{2} \mathrm{PS}_{2}\right]_{6} \mathrm{Zn}_{4} \mathrm{O}+} \\
& \quad\left[(\mathrm{RO})_{2} \mathrm{PS}_{2}\right]\left[(\mathrm{RO})_{2} \mathrm{P}(\mathrm{O}) \mathrm{S}\right] \mathrm{Zn} \longrightarrow \\
& \quad\left[(\mathrm{RO})_{2} \mathrm{PS}_{2}\right]_{5}\left[(\mathrm{RO})_{2} \mathrm{P}(\mathrm{O}) \mathrm{S}\right] \mathrm{Zn}_{4} \mathrm{O}+\left[(\mathrm{RO})_{2} \mathrm{PS}_{2}\right]_{2} \mathrm{Zn}
\end{aligned}
$$

Oxidation to the 'Basic' Structure

$$
\begin{aligned}
3\left[(\mathrm{RO})_{2} \mathrm{PS}_{2}\right]_{2} \mathrm{Zn}+\left[(\mathrm{RO})_{2} \mathrm{PS}_{2}\right]\left[(\mathrm{RO})_{2} \mathrm{P}(\mathrm{O}) \mathrm{S}\right] \mathrm{Zn}+ \\
\quad \mathrm{PhCMe} e_{2} \mathrm{OOH} \longrightarrow \\
\quad\left[(\mathrm{RO})_{2} \mathrm{PS}_{2}\right]_{5}\left[(\mathrm{RO})_{2} \mathrm{P}(\mathrm{O}) \mathrm{S}\right] \mathrm{Zn}_{4} \mathrm{O}+ \\
{\left[(\mathrm{RO})_{2} \mathrm{PS}_{2}\right]_{2}+\mathrm{PhCMe}_{2} \mathrm{OH} }
\end{aligned}
$$

The partially oxidized basic zinc salt, $\left[(\mathrm{RO})_{2} \mathrm{PS}_{2}\right]_{5}$ $\left[(\mathrm{RO})_{2} \mathrm{P}(\mathrm{O}) \mathrm{S}\right] \mathrm{Zn}_{4} \mathrm{O}$, is progressively oxidized, analogous to the Reactions (3A-i), (3B-i), (4-i) and (5-i) (e.g., Reactions (3A-ii) and (5-ii)).

Progressive Oxidation of the Partially Oxidized Basic ZDTP-A

$$
\begin{aligned}
& {\left[(\mathrm{RO})_{2} \mathrm{PS}_{2}\right]_{5}\left[(\mathrm{RO})_{2} \mathrm{P}(\mathrm{O}) \mathrm{S}_{\mathrm{Zn}_{4} \mathrm{O}+}\right.} \\
& \quad 4 \mathrm{PhCMe} \mathrm{C}_{2} \mathrm{OOH} \longrightarrow \\
& \quad 2\left[(\mathrm{RO})_{2} \mathrm{PS}_{2}\right]_{2} \mathrm{Zn}+\left[(\mathrm{RO})_{2} \mathrm{P}(\mathrm{O}) \mathrm{S}\right]_{2} \mathrm{Zn}+ \\
& \quad \mathrm{ZnSO}_{4}+4 \mathrm{PhCMe}_{2} \mathrm{OH}
\end{aligned}
$$

Oxidation to the 'Basic' Structure

$$
\begin{gathered}
3\left[(\mathrm{RO})_{2} \mathrm{PS}_{2}\right]_{2} \mathrm{Zn}+\left[(\mathrm{RO})_{2} \mathrm{P}(\mathrm{O}) \mathrm{S}\right]_{2} \mathrm{Zn}+ \\
\mathrm{PhCMe}_{2} \mathrm{OOH} \longrightarrow \\
\quad\left[(\mathrm{RO})_{2} \mathrm{PS}_{2}\right]_{4}\left[(\mathrm{RO})_{2} \mathrm{P}(\mathrm{O}) \mathrm{S}\right]_{2} \mathrm{Zn}_{4} \mathrm{O}+ \\
{\left[(\mathrm{RO})_{2} \mathrm{PS}_{2}\right]_{2}+\mathrm{PhCMe}{ }_{2} \mathrm{OH}}
\end{gathered}
$$

These reactions proceed until all $(\mathrm{RO})_{2} \mathrm{PS}_{2}$ ligand attached to the 'basic' structure are oxidized to $(\mathrm{RO})_{2} \mathrm{P}(\mathrm{O}) \mathrm{S}$ ligand. Thus, the basic ZDTP is eventually oxidized to 'basic' ZMTP, $\left[(\mathrm{RO})_{2} \mathrm{P}(\mathrm{O}) \mathrm{S}\right]_{6} \mathrm{Zn}_{4} \mathrm{O}$, as summarized in Reaction (6).

$$
\begin{aligned}
{[} & \left.(\mathrm{RO})_{2} \mathrm{PS}_{2}\right]_{6} \mathrm{Zn}_{4} \mathrm{O}+ \\
& (4 n+3(n+m) / 4) \mathrm{PhCMe}_{2} \mathrm{OOH} \longrightarrow \\
& (1-(n+m) / 4)\left[(\mathrm{RO})_{2} \mathrm{P}(\mathrm{O}) \mathrm{S}_{6} \mathrm{Zn}_{4} \mathrm{O}+\right. \\
& (3-n / 2)\left[(\mathrm{RO})_{2} \mathrm{PS}_{2}\right]_{2}+ \\
& ((5 n+3 m) / 4-3)\left[(\mathrm{RO})_{2} \mathrm{P}(\mathrm{O}) \mathrm{S}\right]_{2}+ \\
& n \mathrm{ZnSO}_{4}+m \mathrm{ZnO}+ \\
& (4 n+3(n+m) / 4) \mathrm{PhCMe}_{2} \mathrm{OH}
\end{aligned}
$$

where $n$ and $m$ are the numbers of $(\mathrm{RO})_{2} \mathrm{PS}_{2}$ ligand and zinc atom oxidized, respectively. It should be realized that oxidation of $(\mathrm{RO})_{2} \mathrm{PS}_{2}$ ligand and zinc atom always lead to destruction of the basic structure, so as to yield $\mathrm{ZnSO}_{4}$ and $\mathrm{ZnO}$, respectively. Hence, yield of basic ZMTP can not be $100 \%$ and the maximum yield of basic ZMTP is attained in following cases: (i) zinc atom in the basic structure is consumed only through neutralization by sulfuric acid, which is generated from oxidation of $(\mathrm{RO})_{2} \mathrm{PS}_{2}$ ligand, i.e., $m=0$. (ii) the oxidized ligand, $(\mathrm{RO})_{2} \mathrm{P}(\mathrm{O}) \mathrm{S}$, exists only as a form of basic ZMTP and not as that of disulphide $\left[(\mathrm{RO})_{2} \mathrm{P}(\mathrm{O}) \mathrm{S}\right]_{2}$, i.e., $(5 n+3 m) / 4-3=0$. The maximum yield of the basic ZMTP is calculated to be $1-(n+m) / 4=0.4$, where $m=0$ and $n=2.4$.

In the most simple case, in which basic ZMTP decomposes only to corresponding disulphide $\left.\left[(\mathrm{RO})_{2} \mathrm{P}(\mathrm{O}) \mathrm{S}\right]_{2} * 3\right)$, an overall reaction of basic ZDTP and hydroperoxide that yields zinc free species can be expressed as Reaction (7) by substituting $m=4-n(i . e ., n+m=4)$ in Reaction (6):

$$
\begin{gathered}
{\left[(\mathrm{RO})_{2} \mathrm{PS}_{2}\right]_{6} \mathrm{Zn}_{4} \mathrm{O}+(4 n+3) \mathrm{PhCMe}_{2} \mathrm{OOH} \longrightarrow} \\
\quad(3-n / 2)\left[(\mathrm{RO})_{2} \mathrm{PS}_{2}\right]_{2}+n / 2\left[(\mathrm{RO})_{2} \mathrm{P}(\mathrm{O}) \mathrm{S}\right]_{2}+ \\
n \mathrm{ZnSO}_{4}+(4-n) \mathrm{ZnO}+(4 n+3) \mathrm{PhCMe}_{2} \mathrm{OH}
\end{gathered}
$$

Rossi and Imparato proposed $n=3$, i.e., the same numbers of $\left[(\mathrm{RO})_{2} \mathrm{PS}_{2}\right]_{2}$ and $\left[(\mathrm{RO})_{2} \mathrm{P}(\mathrm{O}) \mathrm{S}\right]_{2}$ are produced from basic ZDTP (Reaction (2)). In the authors' experimental condition, however, 
$\left[(\mathrm{RO})_{2} \mathrm{PS}_{2}\right]_{2}$ is always produced at greater quantities than $\left[(\mathrm{RO})_{2} \mathrm{P}(\mathrm{O}) \mathrm{S}\right]_{2}$ (see Fig. 2, for example). The authors have found that the ratios of $\left[(\mathrm{RO})_{2} \mathrm{PS}_{2}\right]_{2} /\left[(\mathrm{RO})_{2} \mathrm{P}(\mathrm{O}) \mathrm{S}\right]_{2}$ produced from basic ZDTPs are in the range of 1.5-2.0*4). When the ratio of $\left[(\mathrm{RO})_{2} \mathrm{PS}_{2}\right]_{2} /\left[(\mathrm{RO})_{2} \mathrm{P}(\mathrm{O}) \mathrm{S}\right]_{2}$ is two, $n$ is equal to two. Accordingly, one mole of basic ZDTP decomposes eleven moles of hydroperoxide. This means that one mole of ZDTP decomposes three moles of hydroperoxide, which concurs with Burn's report ${ }^{7)}$. The authors thus propose that the number $n$ is in the range of 2-3 and varies with reaction conditions.

Consequently, an overall reaction of the initial homolytic reaction of ZDTP with hydroperoxide, that yields zinc-free organothiophosphate species, could be written:

$$
\begin{aligned}
& {\left[(\mathrm{RO})_{2} \mathrm{PS}_{2}\right]_{2} \mathrm{Zn}+(n+1) \mathrm{PhCMe}_{2} \mathrm{OOH} \longrightarrow} \\
& \quad(1-n / 8)\left[(\mathrm{RO})_{2} \mathrm{PS}_{2}\right]_{2}+n / 8\left[(\mathrm{RO})_{2} \mathrm{P}(\mathrm{O}) \mathrm{S}\right]_{2}+ \\
& \quad n / 4 \mathrm{ZnSO}_{4}+(1-n / 4) \mathrm{ZnO}+(n+1) \mathrm{PhCMe}{ }_{2} \mathrm{OH}
\end{aligned}
$$

The authors have confirmed that the initial homolytic decomposition of hydroperoxide is caused by the zinc-containing species, mainly basic ZDTP. The authors now assume that the second slow stage is the 'induction period', during which active catalysts for the final rapid ionic decomposition of hydroperoxide is being formed from zinc-free organothiophosphate species, such as DS, trisulphide, monosulphide and phosphinoyl disulphide. Investigation of reactions in these second and final stages by using ${ }^{31 P}$ NMR is now on progress in the authors' laboratory. Results of this investigation should appear soon.

\section{Conclusions}

Studies of kinetics and mechanisms by ${ }^{31} \mathrm{P}$ NMR and mass spectrometry were performed for the purpose to investigate the initial homolytic reaction of zinc dialkyldithiophosphates with cumene hydroperoxide in benzene solution. Rate constants for the reaction of ZDTPs and for that of basic ZDTPs with CHP were derived from changes in signal intensities of ZDTPs and basic ZDTPs observed in the in situ ${ }^{31} \mathrm{P}$ NMR analysis. Concentration-time profiles for the reactions of ZDTP and basic ZDTP with cumene hydroperoxide at $70^{\circ} \mathrm{C}$, which are calculated based on kinetic parameters obtained in this study, strongly indicate that basic ZDTP is the major species for the initial homolytic decomposition of hydroperoxide. A large tetrahedral cluster molecule of basic ZDTP was detected in the reaction solution by high resolution mass spectrometric analysis. The identification was made by comparing measured and calculated patterns of the molecular ions which were split into more than ten peaks, according to the isotope ratios of the elements. Oxidation of the basic ZDTP proceeds progressively, in such a way as to change the $(\mathrm{RO})_{2} \mathrm{PS}_{2}$ ligand to $(\mathrm{RO})_{2} \mathrm{P}(\mathrm{O}) \mathrm{S}$ ligand. During this reaction, the tetrahedral zinc skeleton of basic ZDTP is apparently not disrupted.

\section{Acknowledgment}

The authors wish to thank Nippon Oil Co., Ltd. for the permission to publish this paper. The authors also thank anonymous referees for some highly helpful suggestions.

\section{Notes}

*1) It is known that basic ZDTP decomposes thermally to corresponding ZDTP and zinc oxide, even in the absence of hydroperoxides and under rather mild conditions (Reaction $(\mathrm{A}))^{18 \text {. }}$.

$$
\left[(\mathrm{RO})_{2} \mathrm{PS}_{2}\right]_{6} \mathrm{Zn}_{4} \mathrm{O} \longrightarrow 3\left[(\mathrm{RO})_{2} \mathrm{PS}_{2}\right]_{2} \mathrm{Zn}+\mathrm{ZnO}
$$

*2) The authors have confirmed that it is possible for even zinc dialkylmonothiophosphate, $\left[(\mathrm{RO})_{2} \mathrm{P}(\mathrm{O}) \mathrm{S}\right]_{2} \mathrm{Zn}(\mathrm{ZMTP})$, to react with hydroperoxide at rates comparable to that of basic ZDTP/ hydroperoxide reaction, to form 'basic' ZMTP (Reaction (B)). The authors assume that series of Reaction (5-i), (5-ii), ... proceed faster than Reaction (B).

$$
\begin{aligned}
& \quad\left[(\mathrm{RO})_{2} \mathrm{P}(\mathrm{O}) \mathrm{S}\right]_{2} \mathrm{Zn}+\mathrm{PhCMe}_{2} \mathrm{OOH} \longrightarrow \\
& \quad\left[(\mathrm{RO})_{2} \mathrm{P}(\mathrm{O}) \mathrm{S}\right]_{6} \mathrm{Zn}_{4} \mathrm{O}+\left[(\mathrm{RO})_{2} \mathrm{P}(\mathrm{O}) \mathrm{S}_{2}+\mathrm{PhCMe}_{2} \mathrm{OH}(\mathrm{B})\right.
\end{aligned}
$$

*3) The 'basic' ZMTP thus produced may be further oxidized to form various zinc-free phosphorus-containing products. Details of this reaction that finally yields zinc-free organo(thio)phosphate species, will be discussed in the authors' next publication *4) Trisulphide, $\left[(\mathrm{RO})_{2} \mathrm{PS}_{2}\right]_{2} \mathrm{~S}$, and monosulphide, $\left[(\mathrm{RO})_{2} \mathrm{PS}\right] \mathrm{S}_{2}$, which are concurrently formed along with DS, were accounted for as DS, since these sulphides did not suffer oxidation.

\section{References}

1) Kennerley, G.W., Patterson, W.L., Ind. Eng. Chem., 48, 1917 (1956)

2) Larson, R., Sci. Lubr., 10, 12 (1958).

3) Oberright, E.A., Leonardi, S.J., Korzacik, A.P., Meeting of ACS, Division of Petroleum Chemistry, 159 (1958).

4) Holdsworth, J.D., Scott, G., Willams, D., J. Chem. Soc., 4692 (1964).

5) Colclough, T., Cuneen, J.I., J. Chem. Soc., 4790 (1964).

6) Burn, A.J., Adv. Chem. Ser., 75, 323 (1968).

7) Burn, A.J., Cecil, R., Young, V.O., J. Inst. Petrol., 57, 319 (1971).

8) Rossi, E., Imparato, L., Chem. Ind. (Milan), 53, 838 (1971).

9) Bridgewater, A.J., Dever, J.R., Smith, M.D., J. Chem. Soc. Perkin Trans. 2, 1006 (1980).

10) Johnson, M.D., Korcek, S., Zinbo, M., SAE Paper, No. 831684. 
11) Johnson, M.D., Korcek, S., Zinbo, M., ASLE Trans., 29, 136 (1985).

12) For conprehensive reviews on $Z D T P$ reaction mechanism, see e.g., Howard, J.A., "Frontiers of Free Radical Chemistry, ed. by Prior, W.A., Academic Press, New York (1980), p. 237 and Ivanov, S.K., "Developments in Polymer Stabilization-3," ed. by Scott, G., Applied Science Publishers Ltd., Barking, England (1980), p. 55.

13) Willermet, P.A., Mahoney, L.R., Haas, C.M., ASLE Preprint, No. 78-AM-1B-1 (1978).

14) Willermet, P.A., Mahoney, L.R., Bishop, C.M., ASLE Trans, 23, 217 (1979).

15) Willermet, P.A., Mahoney, L.R., Bishop, C.M., ASLE Trans, 23, 225 (1979).

16) Paddy, J.L., Brook, P.S., Waters, D.N., Trib. Trans., 33, 15, (1990).

17) Paddy, J.L., Brook, P.S., Waters, D. N., J. Chem. Soc. Perkin Trans. 2, 1703 (1989).

18) Brunton, G., Gilbert, B.C., Mawby, R.J., J. Chem. Soc. Perkin Trans. 2, 650 (1976).
19) Marshall, G.L., Applied Spectroscopy, 38, 522 (1984).

20) Harrison, P.G., Kikabhai, T., J. Chem. Soc. Dalton Trans. 807 (1987)

21) Harrison, P.G., Kikabhai, Sebald, A., J. Chem. Res., 340 (1991).

22) Harrison, P.G., Kikabhai, T., Inorg. Chim. Acta., 190, 209 (1991).

23) Burn, A.J., Smith, G.W., Chem. Comm., 17, 394 (1965).

24) Sextan, M.D., J. Chem. Soc. Perkin Trans. 2, 1771 (1984).

25) Wystrach, V.P., Hook, E.O., Christpher, G.L.M., J. Org. Chem., 21, 7005 (1956).

26) Ohkatsu, Y., Ueda, H., Kikkawa, K., Osa, T., Yukagaku, 26, 37 (1977).

27) Handley, T.H., Analyt. Chem., 35, 991 (1963).

28) O'Brien, E.L., Beringer, F.M., Mesrobian, R.B., J. Chem. Soc., 79, 6238 (1957).

29) Crutchfield, M.M., Dungan, C.H., "31P Nuclear Magnetic Resonance," John Wiley and Sons Inc., (1967).

30) Ohkatsu, Y., Bull. Chem. Soc. Jpn., 51, 3606 (1978).

31) Yagishita, K., Igarashi, J., unpublished results.

要旨

\title{
${ }^{31} \mathrm{P}$ NMR および MS によるジアルキルジチオリン酸亜鉛と クメンハイドロパーオキサイドの反応の解析（第 1 報） 反応初期のラジカル分解過程について
}

\author{
八木下 和宏，五十嵐 仁一
}

日本石油(株)中央技術研究所， 231 横浜市中区千鳥町 8

ベンゼン中におけるジアルキルジチオリン酸亜鉛（ZDTP） によるクメンハイドロパーオキサイド（CHP）の初期のラジ カル分解反応を， ${ }^{31} \mathrm{P}$ NMR および MS（Mass Spectrometry） を用いて研究した。これまでにこの反応は，ZDTP 自身と CHP によるものおよびこの反応により生じた塩基性ジアルキ ルジチオリン酸亜鉛（b-ZDTP）によるものの二つの段階で進 むことが報告されている。今回 in situ ${ }^{31} \mathrm{P} N \mathrm{NR}$ 法を用いて， より速い ZDTP と CHP の反応については $0 \sim 34^{\circ} \mathrm{C}$, 引き続 いて起こるやや遅い b-ZDTP と CHP の反応については $30 \sim 60^{\circ} \mathrm{C}$, ZDTP とGHP のモル比 $[\mathrm{ZDTP}] /[\mathrm{CHP}]=0.1 \sim$ 0.5 の条件下で ZDTP および b-ZDTP のシグナルの経時変化 を追跡し，二つの反応速度定数拈よびアレニウスパラメーター を決定することができた。得られた二つの反応のアレニウスパ
ラメーターから $70^{\circ} \mathrm{C}$ におけるZDTP および b-ZDTP とCHP の反応速度定数を求め, CHP の初期のラジカル分解過程の反 応プロフィールを計算したところ，ZDTP は短時間で速やか に消耗されており，主要な活性種はZDTP そのものではなく 反応により生じた b-ZDTPであることが明らかになった。 CHP 分解の主要活性種である b-ZDTP について, CHP との 反応機構を ${ }^{31} \mathrm{P} \mathrm{NMR}$ および MS を併用して詳細に検討した。 その結果，MSにより初めて酸素原子を中心として正四面体の 各辺にジチオリン酸配位子をもつ b-ZDTP 分子のイオンピー クの観測に成功するとともに，この b-ZDTP の四面体構造は CHP との反応の過程において見かけ上破壊されることなく, 分子内のジチオリン酸配位子の硫黄原子を酸素原子に置き換え ながら進行することを見い出した。

\section{Keywords}

NMR, MS, Zinc dialkyldithiophosphate, Cumene hydroperoxide, Kinetics 